\title{
Beijing bag kulisserne
}

\section{Jamil Anderlini}

\section{Historien om hvordan mordet på en ukendt britisk forretningsrådgiver udløste den største politiske skandale i Kina i mere end tyve år og ændrede arvefølgen i den politiske top}

Efterhånden som cyaniden begyndte at virke, må Neil Percival Heywood have kigget rundt på de tarvelige fotografier af træer og vandfald på det sennepsgule tapet og undret sig over, hvordan han egentlig var blevet indblandet i den vederstyggelige verden, der kaldes kinesisk politik. Det lurvede hotelværelse på Lucky Holiday Hotel i den kinesiske byprovins Chongqing, hvor Heywood blev fundet død den 15 . november 2011, var fjernt fra hans højere middelklassebarndom i London og uddannelsen på eliteskolen Harrow. Selvom han efterhånden var blevet mere og mere bekymret over sit engagement med en af Kinas mest magtfulde politiske familier og havde set nok til at vide, hvordan de behandlede folk, der kom dem på tværs - havde han fundet det højst usandsynligt, at de ville slå en udlænding ihjel.

Hvad Heywood næppe selv kunne forudse var, at mordet på ham ville udløse den største politiske skandale i Kina i mere end to årtier og blotlægge en magtkamp i eliten, som har rystet det kommunistiske parti i dets grundvold. Efter at have tilbragt næsten halvdelen af sit 41-årige liv i Kina - det meste af tiden som en ubetydelig forretningsrådgiver blev hans død i det afsondrede, nedslidte hotel af politiet i Chongqing tilskrevet 'overdreven alkoholindtagelse'.

Hans lig blev kremeret uden forudgående obduktion. Efter sigende blev Heywoods kinesiske kone presset til at gå med til en hurtig kremering, og hun var så oprevet, at hun fik sin bror og en embedsmand fra det britiske konsulat til at identificere liget. Næsten hele staben på Lucky Holiday Hotel blev de følgende måneder udskiftet, og alle nuværende ansatte er blevet pålagt ikke at diskutere dødsfaldet med nogen.

Hjemme i Storbritannien fik Hey- 
woods familie og venner at vide, at han var død af en blodprop, men nogle af hans gamle skolekammerater var skeptiske. Folk der vidste, hvem han havde forbindelse til i Kina, følte, at sandheden var mere skummel.

Lucky Holiday Hotel var et af Gu Kailais foretrukne steder. Hun var gift med Bo Xilai, der var medlem af kommunistpartiets 25 mand store politbureau, og som styrede Chongqing - en byprovins på størrelse med Østrig og med en befolkning på 33 mio. - som en konge. Den beskedne succes, Haywood havde haft som forretningsrådgiver, stammede fra forbindelsen med Bo-Gufamilien, og det var Gu Kailai, der havde sørget for, at han kom til Chongqing, og installeret ham på det gudsforladte hotel. Det var her hun med hjælp fra en husholderske og en livvagt ved navn Zhang Xiaojun angiveligt skulle have myrdet ham med cyanid opløst i en drink. Den officielle meddelelse om, at hun var blevet anholdt mistænkt for 'overlagt mord', og at hendes mand Bo Xilai var blevet suspenderet fra alle embeder på grund af 'alvorlige disciplinære overtrædelser' sendte chokbølger gennem kinesisk politik.

\section{Bos fald}

En uanseelig britisk rådgivers død havde bragt en af Kinas mægtigste mænd til fald - en mand, der havde været favorit til at indtræde i polit- bureauets stående komite ved det historiske magtskifte senere samme år. Gus og Bos fald har også åbenbaret en dyb kløft i toppen af kommunistpartiet og aflivet illusionen om, at det var lykkedes det autoritære Kina at institutionalisere et velordnet tronskifte i mangel af demokrati. Men Heywoods mistænkelige $d ø d$ ville højst sandsynligt være forblevet en gåde, hvis det ikke havde været for Wang Lijun - fanatisk politimester i Chongqing og engang Bos loyale følgesvend.

Da Wang den 6. februar flygtede fra sin husarrest i Chongqing til USA's konsulat $300 \mathrm{~km}$ væk, blev han den højest placerede embedsmand i det kommunistiske Kinas historie nogensinde, der søgte om asyl, og hans handling vil sandsynligvis gå over i historien som en begivenhed, der ændrede historiens gang. Mens maskinpistolbevæbnede sikkerhedsfolk udsendt af Bo den 7 . februar omringede konsulatet, gav Wang de amerikanske embedsmænd et detaljeret vidneudsagn om Heywoods drab og Gus medvirken såvel som uhyggelige historier om korruption og intriger, der involverede hans tidligere chef.

Wang insisterede på, at Bo prøvede at slå ham ihjel, og anmodede om politisk asyl, og da det blev afslået, indgik han en handel med Beijing og blev en sen nat bragt til hovedstaden af en viceminister for statens sikkerhed. Han er efterfølgende blevet idømt 15 års fængsel for 
magtmisbrug, afhopning, for at have modtaget bestikkelse og for at have bøjet loven til egen fordel.

"Hvis ikke Wang Lijun var løbet til det amerikanske konsulat og havde afsløret omstændighederne omkring Heywoods død, så ville Bo højst sandsynligt være blevet forfremmet til den stående komite, og så ville han have været urørlig" fortalte et højtstående partimedlem i Chongqing-regeringen Financial Times." Det var et skræmmende perspektiv for hans rivaler, der betragter ham som en Hitler-agtig skikkelse".

Selv mange af hans tilhængere mener, at Bo ikke ville have stillet sig tilfreds med en plads som juniormedlem i det kollektive lederskab, men ville have prøvet at manøvrere sig ind på en mere central position - måske ved at erstatte selveste Xi Jinping.

\section{Kinas aristokrati}

Hvis én familie i det post-revolutionære Kina kan betragtes som aristokratisk, så er det Bo Xilais. Hans far Bo Yibo var anfører for den revolutionære Røde Hær - en af de almægtige ældre i partiet, kendt som de otte udødelige, der bag scenen kontrollerede kinesisk politik i 1980'erne og begyndelsen af 1990'erne. Bo Xilai, der er født i 1949, havde en yderst privilegeret opvækst. Han og hans to brødre gik sammen med børn af andre topembedsmænd på eliteskole i Beijing. "Han var meget mere stille og velopdragen end sine to brødre, som var et par arrogante og aggressive slyngler", siger en tidligere klassekammerat. "På overfladen var han venligere og blidere, end de var". Andre beskriver ham som en genert dreng, som rødmede, når han talte.

Men da Mao slap Kulturrevolutionens vanvid løs, og de studerende organiserede sig i rødgardist-grupper, sluttede Bo og hans brødre sig til en yderliggående klike. Disse teenagere troede på 'blodlinje-teorien', som sagde, at det var deres skæbne som sønner af den 'røde adel' at regere Kina. De blev betragtet som særligt ryggesløse, eftersom de angreb regeringsembedsmænd og andre rødgardister, samtidig med at deres forældre - herunder Bos far - blev udrenset eller sendt $\mathrm{i}$ arbejdslejr.

Bos far, Bo Yibo, blev sendt i fængsel, hvor han blev tortureret, og hans mor, Hu Ming, begik selvmord eller blev slået ihjel, mens hun var i rødgardisternes varetægt. Snart rettede udrensningsbølgen sig mod børnene, og Bo Xilai blev kastet i fængsel som 17-årig. Han tilbragte næsten fem år i fængsel og i en arbejdslejr for børn af højere embedsmænd, der var faldet i unåde. Da han blev løsladt i 1972, fik han arbejde på en maskinfabrik.

Folk, der kender Bo, siger, at hans oplevelser gjorde ham bitter. Men han tvivlede aldrig på, at han var speciel og født til at regere. I 1977, 
efter Maos død, kom Bo, der var blevet gift året forinden, ind på et eliteuniversitet i Beijing for at studere historie. Her mødte han den ni år yngre Gu Kailai, der var yngste datter af en prominent revolutionær general. Efter to år på historiestudiet besluttede Bo at skifte til journalistik, og det var her han lagde grunden til sin senere så dygtige manipulering af medierne.

\section{Elsket og frygtet}

Efter at have bestået sin eksamen flyttede Bo til Liaoning-provinsen for at arbejde. Han forlod sin første kone og blev gift med Gu Kailai. I 1993 blev han borgmester i Dalian, ikke mindst takket være sin far, der på det tidspunkt var blevet stærkt interesseret $i$ at fremme sin søns politiske karriere. Det var her i kystbyen med seks mio. indbyggere, at Bo begyndte at udvikle sin særlige politiske stil. Hans charme og tv-tække adskilte ham fra flertallet af grå, anonyme bureaukrater, og han fik hurtigt ry for at få tingene gjort og forbedre folks liv.

Selv i dag husker de fleste ham med varme som en, der gjorde dem stolte af at være fra Dalian. "Måske forstår vi almindelige mennesker ikke til fulde, hvad han var i gang med, men vi syntes alle, han var fantastisk, og han gjorde virkelig meget for byen", siger en indbygger.

Mens det altovervejende offentlige mening om Bo var positiv, kla- gede enkelte over, at han fokuserede for meget på storslåede monumenter og kosmetiske ændringer, især hans besættelse af at plante dyrt, importeret græs. Og i modsætning til sin popularitet i den store offentlighed, så var Bo hadet og frygtet af sine underordnede. "Han var nederdrægtig og ville straffe sine embedsmænd for de mindste ting", siger en, der arbejdede for ham i Dalian. "I selskab med udlændinge og foran kameraerne var han altid smilende, men i det øjeblik han vendte sig mod os, ændrede hans ansigt sig til en tyrans".

Bos enorme magt som øverste kommunistiske embedsmand i Dalian kom til udtryk i andre, mere dystre hændelser. En journalist fra Dalian blev idømt otte års fængsel for undergravende virksomhed og tyveri af statshemmeligheder, efter at han i en Hong Kong-publikation havde skrevet tre anonyme artikler, der kritiserede Bos rolle i en korruptionsskandale.

I mellemtiden havde Gu Kailai også været i gang med at pleje sit image som stjerneadvokat. Hun var stærkt efterspurgt af både kinesiske og udenlandske virksomheder som juridisk rådgiver vedrørende investeringer i Bos 'kongedømme'.

Det var i Dalian i midten af 1990'erne, at Neil Heywood første gang mødte den kommende politiske stjerne og hans glamourøse hustru. Heywood - stadig i tyverne og med håb om at etablere sig som forret- 
ningsrågiver - havde sendt introduktionsskrivelser til politikere og regeringsembedsmænd for at få forbindelse med den kinesiske elite. Bo byens borgmester - svarede, og Heywood med sin britiske overklassecharme blev hurtigt ven med familien, ligesom han blev en del af en gruppe udlændinge, der rådgav Gu i hendes oversøiske forretningseventyr.

Gu flyttede til Bournemouth i Storbritannien med sin søn Guagua, så han kunne komme på sprogskole der, inden han flyttede til Papplewick - en eksklusiv forberedelsesskole for drenge - og endelig Harrow. Neil Haywood fortalte venner, at han havde hjulpet Guagua med at komme ind på den fornemme skole, og de følgende år fungerede han som den unge mands ven og mentor, og optrådte ofte op i selskab med ham og hans mor.

\section{Den stående komite}

Tilbage i Kina tog Bo Xilais karriere fart, og i begyndelsen af $2001 \mathrm{blev}$ han forfremmet til guvernør i Liaoning-provinsen. Analytikere siger, at udnævnelsen var resultat af dels en samordnet smigerkampagne rettet mod Kinas daværende præsident Jiang Zemin dels Bos fars fortsatte kraftige lobby. I 2004 fik Bo sin debut på den globale scene, da han blev udnævnt til handelsminister. Skønt hans løn kun svarede til ca. 12.000 engelske pund om året, boede Bo i et palæ i det centrale Beijing og kørte rundt i en ny Jaguar ud over ministerbilen med chauffør. Hans kone havde tilsyneladende opgivet sin juridiske karriere, men hans søn gik på engelske privatskoler, der kostede 30.000 pund om året.

Efter at Bo i april blev fjernet fra alle poster, har undersøgelser af ikke-offentliggjorte firmaregnskaber afsløret ejendomme og værdier til flere hundrede millioner dollar tilhørende Bos udvidede familie. Papirerne afslører, at Bos brødre og søstre og Gus søstre tilsammen kontrollerer værdier for mindst 120 mio. US\$. Folk tæt på familien hævder, at deres faktiske formue er langt større, men der er ikke fundet beviser på, at disse søskende har gjort noget forkert.

Efter alt at dømme var Bo på kommunistpartiets kongres i 2007 kandidat til at avancere til politbureauets stående komite, der i virkeligheden regerer Kina. Men hans fars død i januar samme år begrænsede hans politiske indflydelse, og den standhaftige modstand fra mange nu- og forhenværende partifunktionærer, inklusive Wen Jiabao, ødelagde i sidste instans hans chancer. Bo blev sendt til provinsen, til den fugtige storby Chongqing i det sydvestlige Kina på Yangtze-floden bred.

"Der var tre ting, der forhindrede ham i at blive forfremmet: Det forhold, at han var berygtet for at have været medlem af en voldelig rød- 
gardist-gruppe, hans dårlige behandling af kolleger og underordnede og faderens dårlige $r y$ og overdrevent aggressive støttekampagne”, siger Cheng Li, der er ekspert i kinesisk politik på Brookings Institution. Der var også en udbredt frygt blandt partiledere og partiældre for, at Bos overvældende ambition ville få han til at prøve at gribe magten, eftersom han, i modsætning til højtstående partimedlemmer, ikke lagde skjul på sit ønske om en dag at blive premierminister eller præsident.

\section{Chongqing-modellen}

Selv om han var vred og frustreret over at blive forvist til udkanten af imperiet, fandt han hurtigt ud af at bruge sin nye position til at styrke sin stilling. Da han kom for at tage over som partisekretær, sydede Chongqing af problemer: En forfærdelig forurening, arbejdsløshed, ukontrolleret vækst, organiseret kriminalitet, korruption og en begyndende boligboble. Han begyndte hurtigt en oprydning - i såvel overført betydning som bogstaveligt med en række tiltag, som tilsammen blev kendt som 'Chongqing-modellen, og som nogen så som et alternativ til de politikker, som Beijing stod for. Ligesom i Dalian lancerede han en omfattende beplantningskampagne for at gøre byen grønnere og smukkere. På hans dagsorden var bl.a. sanering og genopbygning af store byområder, et enormt statsstøt- tet genhusningsprogram for lavindkomstfamilier, bygning af en kolossal ny motorvej, et bro- og tunnelnetværk og en ny lufthavn.

Udenlandske investorer var forblændet af Bo, af hans engelske humor og den vestlige charme, som adskilte ham fra de kommunistiske embedsmænd, de normalt mødte i Kina. Men nøjagtig ligesom i Dalian og i handelsministeriet lærte hans underordnede snart at frygte ham.

\section{Wang Lijun}

For at styrke sin magt over Chongqings politi og sikkerhedstjeneste håndplukkede Bo en mand, som han kendte godt fra sin tid i det nordøstlige Kina, og som han havde forfremmet flere grader til sikkerhedschef. Manden var Wang Lijun, etnisk mongol og dekoreret politimand, der havde ry for at have bekæmpet mafiabandet i det lovløse nordøstlige Kina. Med sine smarte briller og hang til finere skræddersyede habitter var folks første indtryk, at han lignede en professor. Selv om han ikke havde anden uddannelse end politiskolen, var Wang besat af lærdom og kultur og takkede ja til adskillige gæsteprofessorater i ind- og udland.

I de sene 1990'ere havde partiets propagandafolk lagt mærke til Wang og lavede en tv-serie baseret på hans bedrifter, og senere bestilte han selv et antal bøger og film, der glorificerede hans handlinger. Wang var en 
pralhals og fantast, som hæudede at han havde fået en del af sin træning hos FBI, og at han engang havde overtalt kidnappere fra den italienske mafia til at lade ham gå. Han gik ofte i læderjakker, som han påstod var samme mærke, som tidligere præsident Clinton brugte.

Wangs ry og loyalitet over for Bo gjorde ham til præcis den rette mand til at bistå med det, der var blevet hjørnestenen i Bos forsøg på at opnå en højere stilling: en højprofileret krig mod organiseret kriminalitet.

Wang kom til Chongqing i juni 2008, og et år senere lancerede makkerparret deres tv-transmitterede stormløb mod mafiaen. I en serie af hurtige retssager blev mere end et dusin mafiabosser dømt og henrettet, mens flere tusinde fik langvarige fængselsstraffe, og enorme værdier blev konfiskeret. Offentligheden var tilfreds, men snart kom der foruroligende oplysninger om forfølgelse, manglende overholdelse af lovmæssige procedurer og tilståelser opnået ved tortur.

\section{Kommunistisk nostalgi}

Bos andet programpunkt i kampen for en højere post var en nostalgisk kampagne for at genoplive traditionel kommunistisk moral. Regeringskontorer, virksomheder og lokalsamfund blev opmuntret til at bruge store summer på at arrangere fællessang med kulturrevolutionens 'røde' sange for at forherlige landets kommunistiske tradition. Regeringen sms'ede Mao-citater til borgerne, patriotiske historiske dramaer erstattede quiz-programmerne på tv, og reklamer blev bandlyst i den bedste sendetid. Lokalregeringen havde over i købet bestilt en 37 meter høj Mao-statue. Denne besættelse af kommunistisk 'moral' fremkaldte foragt hos folk, der pegede på, at Bos egen søn nu studerede på $\mathrm{Ox}$ ford, hvor han havde ry for at være en forkælet og velhavende hua hua gongzi (blomsterprins).

Mens hendes mand bekæmpede organiseret kriminalitet og sang røde slagsange i Chongqing, og hendes søn førte sig frem som champagne-drengen i Oxford, blev Gu Kailais opførsel mere og mere hektisk. Neil Heywood var omkring 2005-2006 blevet hendes vigtigste forretningsagent i udlandet. I 2008 begyndte han på hendes vegne at forhandle med British Museum om muligheden for, at hun kunne blive museets 'gudmoder' og velynder i Kina. "Han var samtalepartner, indbegrebet af den vestlige mellemmand af den slags, som det er meget almindeligt repræsenterer magtfulde mennesker i Mellemøsten”, ifølge en som var bekendt med diskussionerne. Men samtalerne stoppede i slutningen af 2010, da Heywood diskret fortalte museet, at Gu havde fået et nervesammenbrud og derfor ikke kunne fortsætte med den foreslåede aftale.

På cirka samme tid begyndte Hey- 
wood at fortælle venner, at Gu var 'psykisk ustabil', og han beskrev Bos husholdning som en mærkværdig feudal verden, hvor tjenestaben svor cølibat for at arbejde hos dem. Gus ægteskab med Bo var blevet stadig mere fjernt, efter at hun flyttede til Storbritannien, og det bidrog til hendes depression. I en samtale med en ven den 13. november, to dage før han blev fundet død, virkede Heywood nervøs over at være kaldt til Chongqing for at møde Gu, men han gav ikke udtryk for at være bekymret for sin sikkerhed. I den officielle bekendtgørelse af Gus anholdelse i forbindelse med drabet på Heywood stod, at de det drejede sig om 'en økonomisk konflikt, som var intensiveret'.

\section{Intrigerne}

Politiet mener, at Gu planlagde at myrde Heywood, efter at han krævede en større provision for at hjælpe hende med ulovligt at overføre offentlige midler til udlandet og truede med at afsløre hendes økonomiske aktiviteter i udlandet, hvis hun afslog. Ifølge andre kilder var $\mathrm{Gu}$ blevet mere og mere paranoid og deprimeret, efter at hun havde opdaget, at hun var genstand for en undersøgelse om korruption iværksat af hendes mands utallige politiske fjender. Fire højtstående partimedlemmer med kendskab til sagen hævdede, at magtfulde nu- og forhenværende medlemmer af parti- eliten, der var modstandere af Bos forfremmelse til politbureauets stående komite, havde lanceret en hemmelig undersøgelse for at samle beviser mod ham og hans familie og kolleger. De sagde, at planen var, at konfrontere Bo med disse beviser for at blokere hans vej til toppen af kinesisk politik og tvinge ham til stille og roligt at trække sig tilbage til en mindre prominent position. Disse anstrengelser omfattede også en landvarig undersøgelse af politichef Wang Lijun og især af den rolle, han havde spillet som chef for politiet i den nordøstlige by Tieling, hvor han arbejdede indtil 2003.

Wangs efterfølger som chef for politiet og viceborgmester i Tieling, Gu Fengjie, blev i maj 2011 tilbageholdt af kommunistpartiets antikorruptions-myndighed, efter at mindst to andre højtstående politifolk var blevet arresteret. Som et makabert efterspil blev en anden viceborgmester fundet flydende i en kanal i Liaonings provinshovedstad Shenyang i september i 2011. Ifølge politiet var det selvmord, og de sagde at han havde været deprimeret.

Venner siger, at Neil Heywood næsten helt sikkert var uvidende om den igangværende undersøgelse af Wang og $\mathrm{Gu}$, og det pres, som $\mathrm{Gu}$ derfor var under, og han kunne ikke vide, at hans trusler ville få hende til at skride til en så drastisk handling. Der er kun blevet offentliggjort få detaljer om Heywoods død, men slibrige rapporter, der cirkulerer i 
politiske og diplomatiske cirkler, hævder, at han spyttede den cyanidholdige drink ud, som Gu og hendes medskyldige havde givet ham, og at de derefter holdt ham ned på gulvet og tvang ham til at drikke giften. Hans lig blev fundet i hotelværelset den 15 . november.

I sin senere erklæring til amerikanske diplomater og kinesiske efterforskere sagde Wang Lijun, at han var blevet informeret om sagen af politifolk, som ikke ville godkende kremeringen af Heywood, fordi der ikke var foretaget en obduktion. Wang tog derfor hår- hud- og blodprøver af Heywoods lig, før det blev kremeret den 18.november. Informerede kilder siger, at de mener Wang allerede på det tidspukt vidste, at Gu var ansvarlig for Heywoods $\mathrm{d} ø \mathrm{~d}$, men havde indvilliget $\mathrm{i}$ at dække over det.

Begivenhederne, der førte til Wangs flugt til det amerikanske konsulat i Chengdu $300 \mathrm{~km}$ fra Chongqing, er omgærdet af mystik. Efter sigende fortalte Wang de amerikanske diplomater i Chengdu, at han gik til Bo omkring den 18. januar og oplyste ham om, at han havde bevis på, at Gu havde myrdet Heywood. Bo blev rasende, slog han i ansigtet, råbte ad ham og beordrede ham til at forsvinde.

Der er flere teorier om, hvorfor Wang gik til Bo med sine beviser. Den mest sandsynlige synes at være, at Wang var klar over, at antikorruptionsmyndighedens undersøgelse af ham og hans fortid var ved at lukke sig om ham. I et forsøg på at sikre sig Bos beskyttelse præsenterede han ham for en bombe af en mordsag - underforstået at han kunne få det hele til at forsvinde, hvis Bo garanterede hans sikkerhed. En anden teori er, at Wang enten ikke vidste noget om eller var ligeglad med efterforskningen i Tieling, og at det var hans blinde loyalitet over for Bo, der gjorde at han forregnede sig, da han fortalte, hvad han vidste, og spurgte hvad han skulle gøre. Uanset Wangs motiver så var det i dette øjeblik, at Bos arrogance og følelse af usårlighed vandt over ham.

\section{Bos fatale fejltagelse}

Mere end et dusin personer interviewet til denne artikel mener, at hvis Bo var gået med på at beskytte Wang, så ville Heywoods død aldrig være kommet frem, og Bo ville have været en førende kandidat til en toppost i partiet i efteråret 2012. "Hvis Bo havde været moderat og nede på jorden, så kunne han have passet på Wang, men han så han som et værktøj eller en hund og affærdigede ham - det var hans fatale fejltagelse", siger en analytiker med nære bånd til lederskabet. "Han var ganske enkelt for arrogant, og hans følelse af at være urørlig for stor".

Ikke længe efter, den 2. februar, blev Wang fyret som politichef og i stedet udnævnt til viceborgmester med ansvar for sport, kloakvæsen og 
uddannelse. Den 6. februar sneg Wang sig ud af sit hus forbi de vagter, som Bo havde sat til at holde øje med ham, og kørte de $300 \mathrm{~km}$ til det amerikanske konsulat i Chengdu. Så snart han var indenfor på konsulatet anmodede han om politisk asyl. Som begrundelse angav han, at Bo Xilai forsøgte at myrde ham, og han afleverede beviserne for, at Heywood var blevet myrdet, og at Gu var indblandet.

I stedet for at rejse til Beijing og forklare sin beslutning om at sende sine egne sikkerhedsfolk fra Chongqing for at hente Wang fra det amerikanske konsulat, der hørte under Chengdus jurisdiktion, gjorde Bo noget, som yderligere foruroligede højtstående partifolk. Han fløj til Kunming i det sydvestlige Kina, 650 $\mathrm{km}$ fra Chongqing, og besøgte den militærlejr, der er hjemsted for den enhed, som Bos fader havde kommandoen over under den kommunistiske revolution. Det symbolske besøg understregede hans nære tilknytning til militæret såvel som hans magtfulde herkomst som søn af en revolutionær leder og vidnede om, at han ikke bekymrede sig om Wangs beskyldninger.

Ved åbningen af den årlige Det Kinesiske Folks Politiske Rådgivende Konference den 2. marts dukkede Bo op og gjorde god mine til slet spil over for de 3.000 forsamlede delegerede og journalister. Men på interne regeringsmøder var han bleg af raseri mens han prækede for embedsmænd fra Chongqing og fortalte dem, at Wangs flugt og de rygter, der hvirvlede omkring ham, alt sammen var led i et 'komplot ansporet af udenlandske reaktionære kræfter'. I løbet af de næste to uger optrådte Bo offentligt en halv snes gange. Som en typisk sidste kraftpræstation holdt han endda en totimers pressekonference i forbindelse med Folkekongressen.

\section{Exit}

Tilsyneladende afslappet sagde Bo, at ikke nærmere angivne fjender havde "dannet kriminelle blokke med vidtrækkende sociale bånd $\mathrm{og}$ evne til at forme opinionen" og svinede ham og hans familie til. Han afviste antydninger om, at han var genstand for en undersøgelse eller i politiske vanskeligheder. Fire dage senere, den 14. marts, overværede Bo folkekongressens afslutningsceremoni siddende ved siden af sine politbureaukolleger på scenen i Folkets Store Hal. Han virkede træt og urolig. På et tidspunkt stirrede han op i loftet, som om han bad en stille bøn. Da ceremonien sluttede, og Kinas øverste ledere gjorde sig klar til at forlade scenen, rejste Bo sig hurtigt og skyndte sig ud. Ude i kulissen blev han ført væk af medlemmer af den eliteenhed, der har til opgave at beskytte Kinas topledere. Samtidig blev Gu og flere end et dusin af Bos nære medarbejdere anholdt. 
Arrestationen af Bo stillede partiet over for et dilemma. Givet Bos store popularitet hos almindelige mennesker kunne en ikke overbevisende officiel redegørelse støttet af forslidte beviser få mange kinesere til at tro, at det hele var et sammensværgelse, og Bo var et offer for en intern politisk magtkamp. Hvis på den anden side retssagen mod han åbenbarede alle de blodige detaljer om korruption, mord og sammensværgelser, kunne befolkningen stille spørgsmålet, hvordan en som ham kunne nå den politiske top, og granskende blikke ville måske rette sig mod de øvrige topledere.

Nogle analytikere mener dog, at der uden Bos destabiliserende tilstedeværelse blev skabt mulighed for et mere harmonisk og effektivt lederskab. "Bo og hans ambitioner blev set som den farligste kraft i kinesisk politik, og folk i partiet sammenlignede ham altid med Hitler", siger en ledende Chongqing-embedsmand, der havde arbejdet tæt sam- men med Bo. "Han var marxistleninist og modstander af liberalt demokrati, men det ironiske er, at hvis det kinesiske folk havde fået lov til at stemme, ville han sandsynligvis være blevet valgt til præsident”.

Gu Kailai blev i august 2012 idømt en betinget dødsstraf, og Bo Xilai blev i september 2013 idømt livsvarigt fengsel.

Jamil Anderlini er Financial Times' bureau chief i Beijing. Ovenstående artikel er en forkortet og opdateret version af en artikel tidligere bragt $i$ Financial Times Weekend magazine. Det foredrag, som Jamil Anderline holdt i Det Udenrigspolitiske Selskab som led i mødercekken 'BRICS and beyond' den 10. december 2012, byggede til en vis grad på denne tidligere publicerede artikel. Artiklen er senere udkommet $i$ en langere udgave som e-bog "The Bo Xilai ScandalDeath, Power and Politics in China". Den fås på Amazon og Kobo.com.

Oversat af Brita V. Andersen. 